\title{
植物の種多様性に基づいた「海上の森」の自然環境評価： 種数・面積関係を用いた種多様性評価手法
}

\author{
中村俊彦 1 .須賀はる子 2 \\ 1千葉県立中央博物館 260-8682 千葉市中央区青葉町955-2 \\ 2 千葉県立中央博物館外来研究員
}

はじめに

2005年の愛知万博は「新しい地球創造 : 自然の䟾 知」をテーマに環境保全や自然保護を掲げる国際博 覧会である。しかし，その会場は瀬戸市「海上の森」 という極めて自然豊かな地に設定され，限られた地 域に多くの入場者を受け入れるための様々な施設づ くりや万博跡地での巨大な住宅開発が予定され，そ の実施は多くの市民・住民や研究者からむしろ自然 破壊に等しいことが指摘されてきた（日本自然保護 協会, 1997 ; 吉田, 1999).

このような問題を生じさせた原因の一つに会場の 海上の森の自然環境に対する評価が明確でなかった ことが上げられる. 万博計画の担当者は海上の森の 自然の特徵やその重要性を理解できないままプロジ エクトの推進をはかろうとしているが, 賛成, 反対 を問わずこれに係わる研究者もその評価を明確に示 してはいない.

開発等のために自然環境評価が必要となつた場合, 対象地の自然の状況を充分に把握すると共にその状 況を他と比較対照することも重要である. 今回, さ まざまな地域のフロラの調査データから植物の種多 様性（種密度）をもとめ, これに基づく海上の森の 自然環境評価を試みた。

\section{生物多様性の意義}

細胞レベルから組織や個体, 種や生態系のレベル まで, 全ての生命体は, 同レベルまた異なるレベル にかかわらず，さまざまな関係の中で各生命体の維 持・存続がはかられている. また，それぞれの生命 体は, 自然界の予測しがたい多くの外因にさらされ， 時には傷つき被害を受けることがある.

ある地域の生態系に異変が生じた場合, これまで はさほど目立たなかった種が生態系の回復に大きな 働きをすることがあり得る. したがって，その生態 系及びこれを構成する種間の健全なバランスの確保 には, 希少種や優占種はもちろんもことあらゆる種 の存続が重要となる. 生物多様性は, 生態系の恒常 性とともにこれに関係するすべての生物を支える基 盤であり，また不測の事態の保険的役割を担うもの である。

生物多様性は, 近年, 特に自然保護や環境保全の
大きな柱としてその重要性が指摘されているが, こ れは，一般に各レベルの単位空間（面積）当たりの 構成要素の種類数とその量的配分状況によって定義 される．すなわち種レベルの多様性は面積当たりの 種数が多くなるほど，またその量的配分が平均化す るほど種の多様性は高くなる。

\section{各地の生物種リストの利用}

生物種のリストづくりは, 地域の自然環境を把握 するのに最も基本的な事項であるが，これに対応で きる専門家は少なく, また, 調査にかかる労力・時 間は大きい. したがって我が国の生物種の生息・分 布等の基礎的情報は極めて不充分である. しかしな がら，近年では自然保護や環境保全に対する社会的 意識の高まりもあって，都道府県や市町村，あるい は地域単位での野生の動植物種についてのリストづ くりが進められ, 各地で植物誌や自然環境調査報告 書が刊行されてきている.

今回は，まず愛知万博の環境影響評価準備書をは じめ, 各地の植物誌や自然環境に係わる報告書等の 出版物で公表されている維管束植物の種リス卜（変 種，亜種，帰化種を含む）を元にして，対象地の面 積と出現種数との関係をグラフ化し解析した.

今回用いたデー夕は 1 ha以上 10 万ha以下の地の 66 ヶ所であり，本報の文献闌にその出所を示した．た だ，清和の森（千葉県清和県民の森）の種数につい ては，これまで千葉県立中央博物館山の博物館（仮 称）建設予定地およびその周辺域約 $600 \mathrm{ha}$ で調査さ れた1999年9月時点での未発表データを用いた.

\section{維管束植物の出現種数と面積との関係}

今回用いたデータの中で維管束植物の種数が最も 多かったのは, 愛知県豊橋市の1,519種 (2,599ha) であった。また，その最小は千葉県市原市国分寺台 東地区84種であった。

全体的に, 対象面積 ( $\mathrm{x}$ ) が増加すれば種数 ( y ) も増加する傾向にあるが，両者の間には， r 2= 0.6573 の相関となる以下のような関係式（対数4次 多項式）が導きだされた（図1上）。

$$
\begin{aligned}
y= & -1.3518(\log x)^{4}+46.101(\log x)^{3}-172.7(\log x)^{2} \\
& +264.25(\log x)+133.02
\end{aligned}
$$



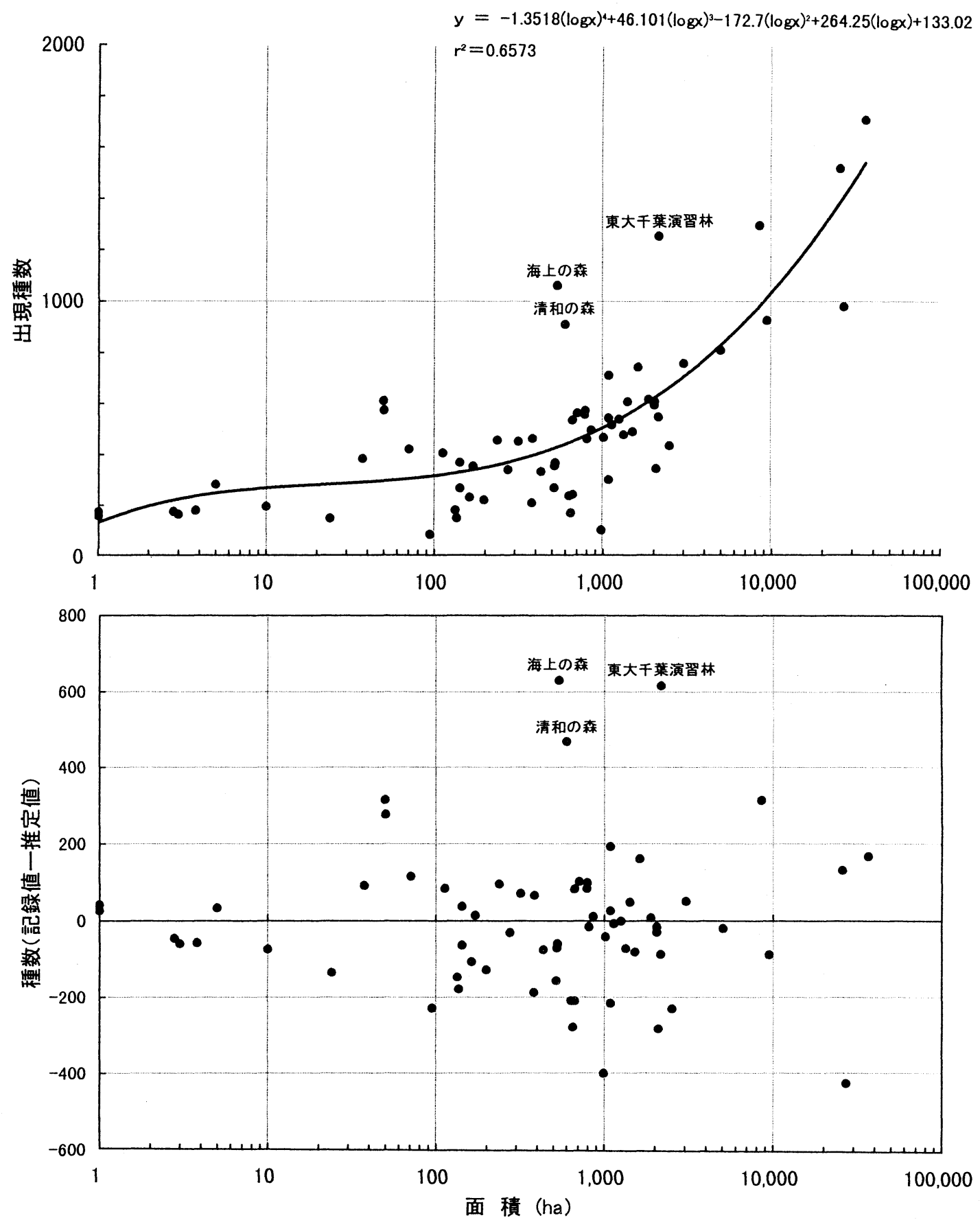

図1. 維管束植物の種数と面積関係.

この式を用いれば，1haから10万haの面積の地域に 540haから1,062種の植物が記録された「海上の森」 おける維管束植物の平均的出現種数が推定できるこ であった. その推定值は 431 種であり, 記録值から とになる. 次に, この理論推定値と実際に調査記録 推定值を引いた值は631種であった. 理論值と記録 された数値との差を全66の対象地で算出し示した 值の差が 2 番目に高い地域は「東大千葉演習林」の (図1下)。 617 種(2,171 haに1,254種記録)，3番目が「清和の

この推定值と記録值との差が最も高かったのは，森」の（600haに911種記録）であった. 


\section{海上の森の種多様性評価}

フロラの記録値と関係式からの理論推定值との差 は「海上の森」が最大であり，これを上回るものは なかった．海上の森に近い值をもつ地として以下の 2つの地域があった。

まず，東大千葉演習林（東京大学農学部附属千葉 演習林）である. 1894年に我が国最初の大学演習林 となった東大千葉演習林は 100 年以上の歴史を持つ 世界の暖温帯植生研究の最も重要な場所である. 房 総半島の清澄山系の標高 $50 \mathrm{~m} \sim 370 \mathrm{~m}$ の丘陵地域で, 標高域としては海上の森と類似している.

千葉県清和県民の森の千葉県立中央博物館山の分 館（仮称）の観察エリアの予定地には，国指定の天 然記念物「高宕山ニホンザル生息地」をはじめ県立 自然公園特別地域や千葉県自然環境地区特別地区等 が含まれている．またこの地域の面積は海上の森の 万博予定地 (540ha) に近い600haである. 維管束 植物についての調查は, 千葉県立中央博物館の研究 職員が中心になって綿密におこなわれているが, 海 上の森の1,062種に対し，1999年9月時点での記録 は911種である.

このような種多様性（種密度）の状況から，海上 の森の自然環境の豊かさ及びその重要性は，少なく とも上記 $2 つ$ 地点に匹敵するものであると判断でき る.

今回は限られた情報と時間の中で, フロラ調査が 比較的充実しており, また海上の森と同じ暖温帯植 生域に属する千葉県の情報を多く用いた。 今後, 基 礎となる地域フロラの調査が進み, 今回の解析方法 の中にさらに多くのデータが追加されれば当然上記 の関係式は変わり, 評価も変わってくるものである. 地域の生物種情報の充実は, 当然今回の評価手法の 汎用性および信頼性を高めるものであるが，我々が 最も気にしなければならないことは，その時まで現 状の自然環境が守っていけるかどうかである.「デ 一夕が充実し研究方法が確立したときには，もはや 自然はなくなっていた」では研究及び研究者の存在 意義はない.

\section{データ文献}

千葉県環境部自然保護課(編)。1987. 千葉県自然環境保全 地域等適地調査. $309 \mathrm{pp}$. 千葉県環境部自然保護課.

千葉県立中央博物館. 1997. 千葉県立中央博物館山の分館 (仮称)環境調查 : 社会環境編. 48pp. 千葉県立中央博物 館.

大栄町史編さん委員会(編). 1997. 大栄町史 - 自然編. 473pp. 千葉県大栄町.

船橋市環境部環境保全課(編)。1995．船橋市自然環境調査 報告書. 208pp. 船橋市環境部環境保全課.

市原市自然環境実態調査団(編)。1994。市原市自然環境実 態調査報告書. 440pp. 市原市環境部環境保全課.

住宅都市整備公団千葉開発局・緑生研究所編(編)。1 1993. 千葉県北部地区印西総合公園報告書. 355 pp. 住宅都市 整備公団千葉開発局.

霧ヶ峰湿原植物群落調査研究委員会(編). 1998. 霧ヶ峰湿 原植物群落調查研究会報告書. $223 \mathrm{pp}$. 諏訪市教育委員 会.

北区環境保全課(編)，1987．北区植物調查報告書．108pp. 東京都北区.

習志野市市民経済部公害センター(編)。1990，習志野市自 然環境調查報告書. 264pp. 習志野市.

日本国際博覧会協会．1999．2005年日本国際博覧会に倸わ る環境影響評価書. 969pp. 日本国際博覧会協会.

沼田眞(監). 1997. 湾岸都市の生態系と自然保護. 1059 pp. 信山社サイテック.

緑生研究所. 1988. 松戸市 21 世紀の森と広場自然環境保 全基礎調查. $193 \mathrm{pp}$. 松戸市公園緑地部.

袖ケ浦市史基礎資料調查会(編). 1997. 袖ヶ浦の植物. $123 p p$. 千葉県袖ヶ浦市教育委員会.

東京大学農学部附属演習林. 1985. 演習林 $24: 13-63$.

東京大学農学部附属演習林. 1994. 演習林百周年 1994.

38pp. 東京大学農学部附属演習林.

豊橋市自然環境調査会(編).1999。豊橋市自然環境保全基 礎調査報告書. 449pp. 豊橋市保健環境部環境対策課.

\section{引用文献}

日本自然保護協会. 1997. 2005年愛知万博構想を検証する： 里山自然の価値と「海上の森」。141 pp. 日本自然保護 協会.

吉田正人. 1999.アセスメントシンポジウムを開催 : 愛知 万博は分散開催へ. 自然保護439:3-4. 